\title{
Berichte der Bunsen-Gesellschaft für physikalische Chemie
}

(C) VCH Verlagsgesellschaft mbH, D-6940 Weinheim, 1988 - Printed in the Federal Republic of Germany 


\title{
Photochemistry of Azide Complexes of Gold, Silver, Platinum, and Palladium. Generation of the Metallic State
}

\author{
A. Vogler, C. Quett, and H. Kunkely
}

Institut für Anorganische Chemie, Universität Regensburg, Universitätsstraße 31, D-8400 Regensburg, Federal Republic of Germany

Colloides / Complex Compounds / Metals / Photochemistry / Spectroscopy, Ultraviolet

The photochemistry of the following azide complexes in organic solvents has been investigated: $\left[\mathrm{Au}\left(\mathrm{N}_{3}\right)_{4}\right]^{-},\left[\mathrm{Au}\left(\mathrm{N}_{3}\right)_{2}\right]^{-},\left[\mathrm{Ag}(\mathrm{PPh})_{2} \mathrm{~N}_{3}\right]$, $\left[\mathrm{Pt}\left(\mathrm{N}_{3}\right)_{6}\right]^{2-},\left[\mathrm{Pt}\left(\mathrm{N}_{3}\right)_{4}\right]^{2-},\left[\mathrm{Pd}\left(\mathrm{N}_{3}\right)_{4}\right]^{2-}$, and $\left[\mathrm{Pd}_{2}\left(\mathrm{~N}_{3}\right)_{6}\right]^{2-}$. All complexes underwent a photochemical reduction of the metal and oxidation of azide upon ligand to metal charge transfer excitation. The photolysis of the complexes with the metals in the lower oxidation states $(\mathrm{Au}(\mathrm{I}), \mathrm{Ag}(\mathrm{I}), \mathrm{Pt}(\mathrm{II}), \mathrm{Pd}(\mathrm{II}))$ led ultimately to the generation of free metals which form colloids. These colloids were characterized by their absorption spectra which showed the typical plasmon bands in the case of gold and silver. $\operatorname{Pt}(0)$ and $\operatorname{Pd}(0)$ produced during the photolysis can be intercepted with allyl chloride to form $[\mathrm{Pt}(\pi \text {-allyl }) \mathrm{Cl}]_{4}$ and $[\mathrm{Pd}(\pi \text {-allyl }) \mathrm{Cl}]_{2}$. Most photoreactions took place with rather large quantum yields.

\section{Introduction}

The photochemistry of transition metal azide complexes has been investigated extensively [1-25]. Almost any azide complex seems to be light sensitive regardless of the metal and its oxidation state. Three types of photoreactions were observed. In a few cases the azide ligand undergoes a photosubstitution $[15,16]$. Oxidizing metals are frequently photoreduced by the azide ligand while the photolysis of azide complexes of other metals leads to the generation of coordinated nitrenes. The interdependence of these reaction modes was the subject of several studies $[12,13,17,19,22$, 25].

Suitable complexes which contain more than one azide ligand may undergo multielectron photoreduction of metal ions in higher oxidation states. Photochemical reductive eliminations are typical reactions of this type [20, 21, 23, 24]. Homoleptic azide complexes are good candidates for such studies [24]. The photoreaction of appropriate homoleptic azide complexes containing oxidizing metal centers may finally yield the metal in the oxidation state zero. In the absence of $\pi$-accepting ligands naked metal atoms should be formed first.

Since the metal atoms are very energy rich they are expected to react with the medium or agglomerate to clusters and larger particles $[26,27]$. In contrast to thermal reductions of metal compounds the photochemical generation of the metallic state can be controlled much better by a suitable choice of temperature, light intensity, and other reaction parameters. The photoformation of free metals may also be an interesting alternative to the metal-vapor cocondensation technique [28-30]. Although the latter method is widely applicable it requires sophisticated instrumentation. In contrast, the photogeneration of free metals seems to be a very simple procedure to generate metal atoms or clusters under a variety of experimental conditions including low-temperature matrices. By time-resolved spectroscopy it may be possible to study the mechanism of conversion of metal atoms to smaller clusters, larger clusters and metal colloids under ambient conditions.

The photogeneration of small metal particles under wellcontrolled conditions is certainly also of interest with regard to heterogeneous catalysis [31]. It should be possible to prepare bimetallic particles which are not easily obtained by other methods. The deposition of metals on semiconductor materials can be carried out photochemically. New processes of electroless metal deposition as applied to the production of electronic devices may be developed on the basis of the direct photoreduction to the metallic state.

Although some photoreactions which yield free metals in homogeneous solutions are known [5, 24, 32-34] this interesting and important part of inorganic photochemistry has not yet been advanced very much. The present study describes the photogeneration of gold, silver, platinum, and palladium by the photolysis of azide complexes. As an important feature the metals are formed in non-aqueous solvents. This extends the range of possible applications. No attempt was made to detect and characterize reactive intermediates which are formed in the photolysis. However, it is anticipated that our contribution will stimulate further investigations in this direction.

\section{Experimental Section}

\section{Materials}

The salts $\left[\mathrm{N}\left(\mathrm{C}_{4} \mathrm{H}_{9}\right)_{4}\right]\left[\mathrm{Au}\left(\mathrm{N}_{3}\right)_{4}\right], \quad\left[\mathrm{N}(\right.$ cetyl $\left.)\left(\mathrm{CH}_{3}\right)_{3}\right]\left[\mathrm{Au}\left(\mathrm{N}_{3}\right)_{4}\right]$, $\left[\mathrm{N}\left(\mathrm{C}_{4} \mathrm{H}_{9}\right)_{4}\right]\left[\mathrm{Au}\left(\mathrm{N}_{3}\right)_{2}\right],\left[\mathrm{N}\left(\mathrm{C}_{4} \mathrm{H}_{9}\right)_{4}\right]_{2}\left[\mathrm{Pt}\left(\mathrm{N}_{3}\right)_{6}\right],\left[\mathrm{N}\left(\mathrm{C}_{4} \mathrm{H}_{9}\right)_{4}\right]_{2}\left[\mathrm{Pt}\left(\mathrm{N}_{3}\right)_{4}\right]$ $\left[\mathrm{N}\left(\mathrm{C}_{4} \mathrm{H}_{9}\right)_{4}\right]_{2}\left[\mathrm{Pd}\left(\mathrm{N}_{3}\right)_{4}\right]$, and $\left[\mathrm{N}\left(\mathrm{C}_{4} \mathrm{H}_{9}\right)_{4}\right]_{2}\left[\mathrm{Pd}\left(\mathrm{N}_{3}\right)_{6}\right]$ were prepared as described by Beck et al. [4]. However, according to this report the complex anions were isolated as $\left[\mathrm{As}\left(\mathrm{C}_{6} \mathrm{H}_{5}\right)_{4}\right]^{+}$salts. Since this cation absorbs in the UV region it interferes with the spectra and photochemistry of the complexes. For this reason all complex anions were isolated as salts of the non-absorbing counter ions $\left[\mathrm{N}\left(\mathrm{C}_{4} \mathrm{H}_{9}\right)_{4}\right]^{+}$or $\left[\mathrm{N}(\text { cetyl })\left(\mathrm{CH}_{3}\right)_{3}\right]^{+}$[35]. The neutral complex $\left[\mathrm{Ag}\left(\mathrm{PPh}_{3}\right)_{2} \mathrm{~N}_{3}\right]$ was also synthesized according to a published procedure [9]. The electronic absorption spectra agreed well with those reported previously $[4,35]$. In some cases $\left(\left[\mathrm{N}\left(\mathrm{C}_{4} \mathrm{H}_{9}\right)_{4}\right]\left[\mathrm{Au}\left(\mathrm{N}_{3}\right)_{4}\right]\right.$, $\left.\left[\mathrm{N}\left(\mathrm{C}_{4} \mathrm{H}_{9}\right)_{4}\right]_{2}\left[\mathrm{Pd}\left(\mathrm{N}_{3}\right)_{4}\right],\left[\mathrm{N}\left(\mathrm{C}_{4} \mathrm{H}_{9}\right)_{4}\right]_{2}\left[\mathrm{Pd}_{2}\left(\mathrm{~N}_{3}\right)_{6}\right],\left[\mathrm{Ag}\left(\mathrm{PPh}_{3}\right)_{2} \mathrm{~N}_{3}\right]\right)$ the purity of the compounds was confirmed by elemental analysis.

\section{Caution:}

All metal azide compounds are potentially explosive [4]. This is particularly true for the alkali salts of the complex anions described above. The alkali salts tend to explode even if they are wet. This tendency is greatly reduced if the azide complexes are isolated as salts with large organic cations such as $\left[\mathrm{N}\left(\mathrm{C}_{4} \mathrm{H}_{9}\right)_{4}\right]^{+}$. Further precautions are mentioned in the paper by Beck et al. [4]. 
All solvents used in the photochemical experiments were spectro grade.

\section{Photolyses}

The light sources were an Osram HBO $100 \mathrm{~W} / 2$, an Osram HBO $200 \mathrm{~W} / 2$, an Osram XBO $450 \mathrm{~W} / 4$, and a Hanovia Xe/Hg 977 B-1 (1000-W) lamp. The following Schott cut-off filters were used to avoid short-wavelength irradiation: WG 305, WG 335, GG 395. The Schott broad band glass filter UG 11 limited the irradiation to wavelengths from 270 to $380 \mathrm{~nm}$. The following Schott interference filters PIL were used for the irradiation at selected wavelengths: $254,313,333,366,405$, and $436 \mathrm{~nm}$. When the photolysis was carried out with the xenon lamp monochromatic light was obtained by means of a Schoeffel GM 250-1 high-intensity monochromator. The photolyses were carried out at room temperature in 1-cm spectrophotometer cells. For quantum yield determinations the complex concentrations were such as to have essentially complete light absorption. The total amount of photolysis was limited to less than $5 \%$ to avoid light absorption by the photoproduct. Absorbed light intensities were determined by a Polytec pyroelectric radiometer, which was calibrated and equipped with a RkP-345 detector.

Progress of the photolysis was generally monitored by UV-visible spectrophotometry using a Varian-Techtron Super Scan 3 recording spectrophotometer or a Kontron Uvikon 810 spectrophotometer. The nitrogen which was evolved in the photolysis was determined by gas chromatography (Perkin Elmer GC 8500). A sealed GC glass tube (6 mL volume) which contained $1 \mathrm{~mL}$ of solution of the complex was irradiated. A gas sample was then drawn from the head space and injected in the GC instrument. The measured amount of $\mathrm{N}_{2}$ was compared with that of blank samples kept in the dark. Since the GC glass tubes transmitted light only at $\lambda>280 \mathrm{~nm}$ photolyses which required shorter-wavelength irradiation $\left(\left[\mathrm{Au}\left(\mathrm{N}_{3}\right)_{2}\right]^{-},\left[\left(\mathrm{PPh}_{3}\right)_{2} \mathrm{AgN}_{3}\right],\left[\mathrm{Pt}\left(\mathrm{N}_{3}\right)_{4}\right]^{2-}\right)$ were carried out in an optical quartz cell $(3 \mathrm{~mL})$. This cell was connected to a constantpressure gas buret. The following stochiometric $\mathrm{N}_{2}$ to metal ratios were found (experimental error $\pm 10 \%$ ): $\left[\mathrm{Au}\left(\mathrm{N}_{3}\right)_{4}\right]^{-}: 3.2$; $[\mathrm{Au}-$ $\left.\left(\mathrm{N}_{3}\right)_{2}\right]^{-}: 1.6 ;\left[\left(\mathrm{PPh}_{3}\right)_{2} \mathrm{AgN}_{3}\right]: 1.4 ;\left[\mathrm{Pt}\left(\mathrm{N}_{3}\right)_{6}\right]^{2-}: 3.1 ;\left[\mathrm{Pt}\left(\mathrm{N}_{3}\right)_{4}\right]^{2-}: 2.7$; $\left[\mathrm{Pd}_{2}\left(\mathrm{~N}_{3}\right)_{6}\right]^{2-}: 3.0 ;\left[\mathrm{Pd}\left(\mathrm{N}_{3}\right)_{4}\right]^{2-}: 2.9$.

\section{Gold}

\section{Results}

Upon irradiation $\left(\lambda_{\text {irr }}=333 \mathrm{~nm}\right)$ or $\left[\mathrm{Au}\left(\mathrm{N}_{3}\right)_{4}\right]^{-}$dissolved in tetrahydrofurane, acetonitrile, and other organic solvents spectral changes (Fig. 1) were observed indicating a clean conversion to $\left[\mathrm{Au}\left(\mathrm{N}_{3}\right)_{2}\right]^{-}$which has an absorption maximum at $218 \mathrm{~nm}$. The irradiation was accompanied by the formation of molecular nitro-

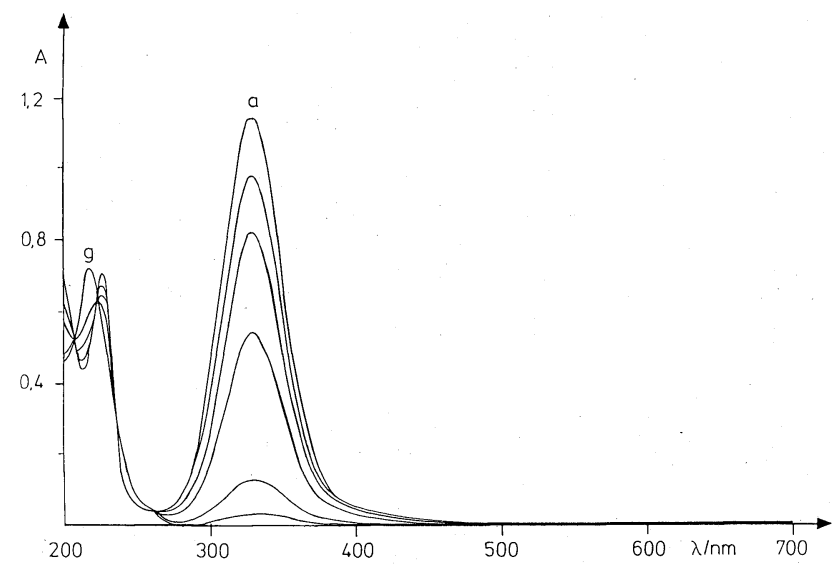

Fig. 1

Spectral changes during the photolysis of $4.75 \cdot 10^{-5} \mathrm{M}\left[\mathrm{Bu}_{4} \mathrm{~N}\right]$ $\left[\mathrm{Au}\left(\mathrm{N}_{3}\right)_{4}\right]$ in $\mathrm{CH}_{3} \mathrm{CN}$ at (a) 0 and (g) 5 min irradiation time, $\lambda_{\text {irr }}=$ $333 \mathrm{~nm}, 1-\mathrm{cm}$ cell gen. Since $\left[\mathrm{Au}\left(\mathrm{N}_{3}\right)_{2}\right]^{-}$absorbs only below $320 \mathrm{~nm}$ the photolysis can be driven to completion. The disappearance of $\left[\mathrm{Au}\left(\mathrm{N}_{3}\right)_{4}\right]^{-}$was followed by measuring the decrease of extinction at the band maximum of $\left[\mathrm{Au}\left(\mathrm{N}_{3}\right)_{4}\right]^{-}(\lambda=331 \mathrm{~nm})$. In $\mathrm{CH}_{3} \mathrm{CN}$ as solvent the photolysis $\left(\lambda_{\text {irr }}=333 \mathrm{~nm}\right)$ took place with a quantum yield of $\phi=$ 0.51 .

The photolysis of $\left[\mathrm{Au}\left(\mathrm{N}_{3}\right)_{2}\right]^{-}$which took place in a variety of organic solvents, required light of very short wavelength $(<320 \mathrm{~nm})$. The irradiation led to the formation of nitrogen, free azide, and colloidal gold. The accompanying spectral changes are shown in Fig. 2. The new band at $540 \mathrm{~nm}$ is the characteristic plasmon absorption of colloidal gold [36-39]. It appeared much more pronounced upon photolysis of $\left[\mathrm{Au}\left(\mathrm{N}_{3}\right)_{2}\right]^{-}$at higher concentrations. Further remarkable features of the photoproduct appear below $240 \mathrm{~nm}$. Narrow bands can be recognized at $\lambda_{\max }=204,212$, 227 , and $238 \mathrm{~nm}$. The disappearance of $\left[\mathrm{Au}\left(\mathrm{N}_{3}\right)_{2}\right]^{-}$was determined by measuring the drop of extinction at the absorption maximum

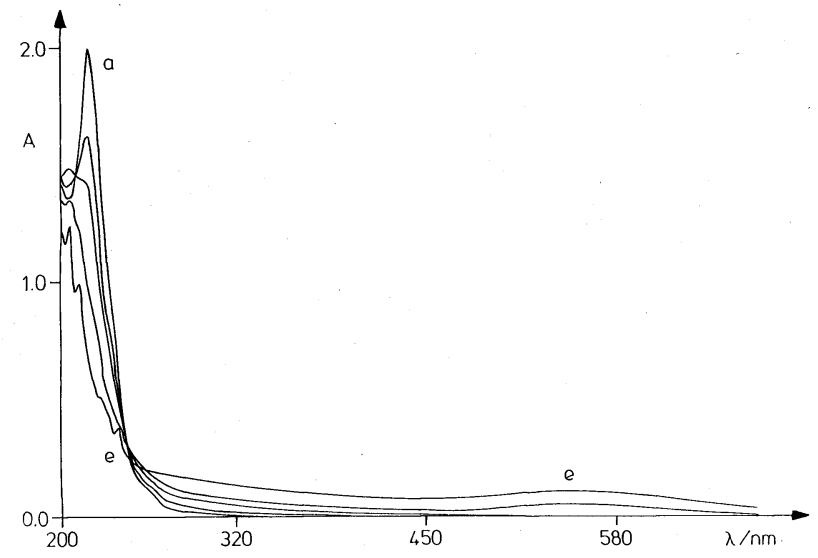

Fig. 2

Spectral changes during the photolysis of $1.29 \cdot 10^{-4} \mathrm{M}\left[\mathrm{Bu}_{4} \mathrm{~N}\right]-$ $\left[\mathrm{Au}\left(\mathrm{N}_{3}\right)_{2}\right]$ in $\mathrm{CH}_{3} \mathrm{CN}$ at (a) 0 and (e) 30 min irradiation time, white light, 1-cm cell

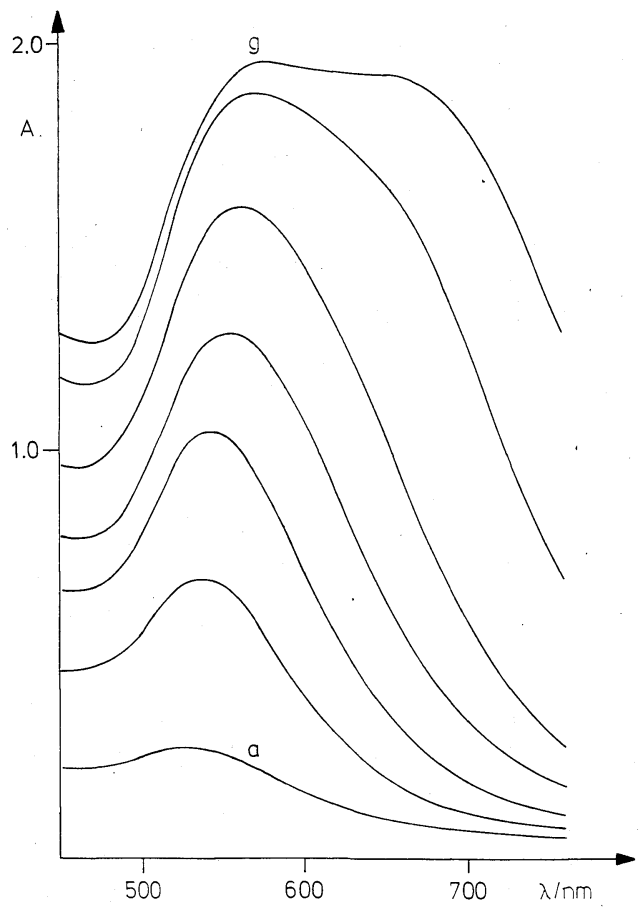

Fig. 3

Spectral changes during the photolysis of $8 \cdot 10^{-4} \mathrm{M}\left[\mathrm{Bu}_{4} \mathrm{~N}\right]-$ $\left[\mathrm{Au}\left(\mathrm{N}_{3}\right)_{4}\right]$ in DMF at (a) 5 and (g) 80 min irradiation time, white light, $1-\mathrm{cm}$ cell 
of $\left[\mathrm{Au}\left(\mathrm{N}_{3}\right)_{2}\right]^{-}(\lambda=218 \mathrm{~nm})$ taking into account a residual absorption of the photolysis product of $\sim 30 \%$. The disappearance quantum yield of $\left[\mathrm{Au}\left(\mathrm{N}_{3}\right)_{2}\right]^{-}$in acetonitrile was $\phi=0.20$ at $\lambda_{\text {irr }}=$ $254 \mathrm{~nm}$.

The photochemical formation of colloidal gold was studied in more detail. In most cases it was produced by the irradiation of $\left[\mathrm{Au}\left(\mathrm{N}_{3}\right)_{4}\right]^{-}$with white light. It follows that the photolysis of $\left[\mathrm{Au}\left(\mathrm{N}_{3}\right)_{4}\right]^{-}$was followed by the secondary photolysis of $[\mathrm{Au}-$ $\left.\left(\mathrm{N}_{3}\right)_{2}\right]^{-}$. A typical example is the photoreaction of $\left[\mathrm{Au}\left(\mathrm{N}_{3}\right)_{4}\right]^{-}$in $\mathrm{DMF}$. The color of the colloidal gold changed from red to violet and finally blue during the photolysis. The accompanying spectral changes are shown in Fig. 3. When $\left[\mathrm{N}\left(\mathrm{C}_{4} \mathrm{H}_{9}\right)_{4}\right]\left[\mathrm{Au}\left(\mathrm{N}_{3}\right)_{4}\right]$ which was used in most experiments was replaced by the $\left[\mathrm{N}(\operatorname{cetyl})\left(\mathrm{CH}_{3}\right)_{3}\right]^{+}$ salt it was possible to dissolve the complex in solvents of very low polarity such as ether, $\mathrm{CCl}_{4}$, and toluene. Even in those solvents the photolysis led to the appearance of the plasmon absorption of colloidal gold.

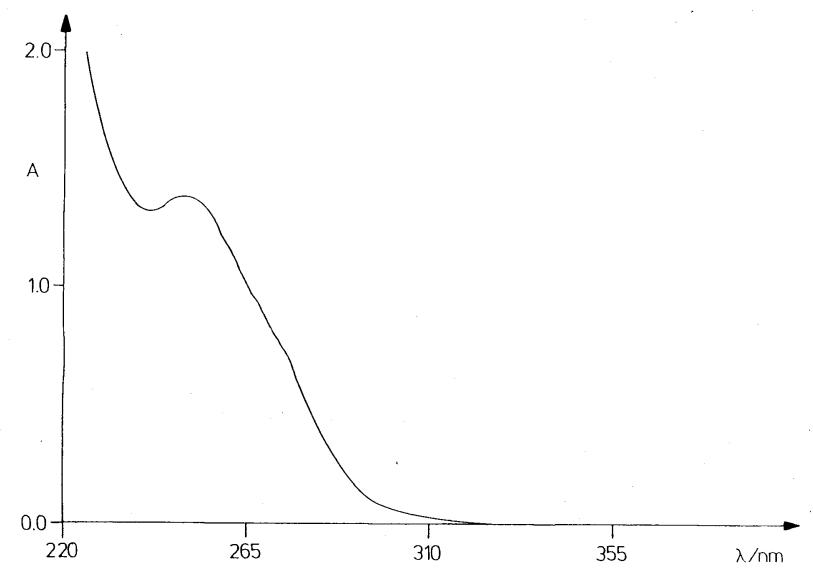

Fig. 4

Electronic absorption spectrum of $6.87 \cdot 10^{-5} \mathrm{M}\left[\mathrm{Ag}\left(\mathrm{PPh}_{3}\right)_{2} \mathrm{~N}_{3}\right]$ in $\mathrm{CH}_{3} \mathrm{CN}$

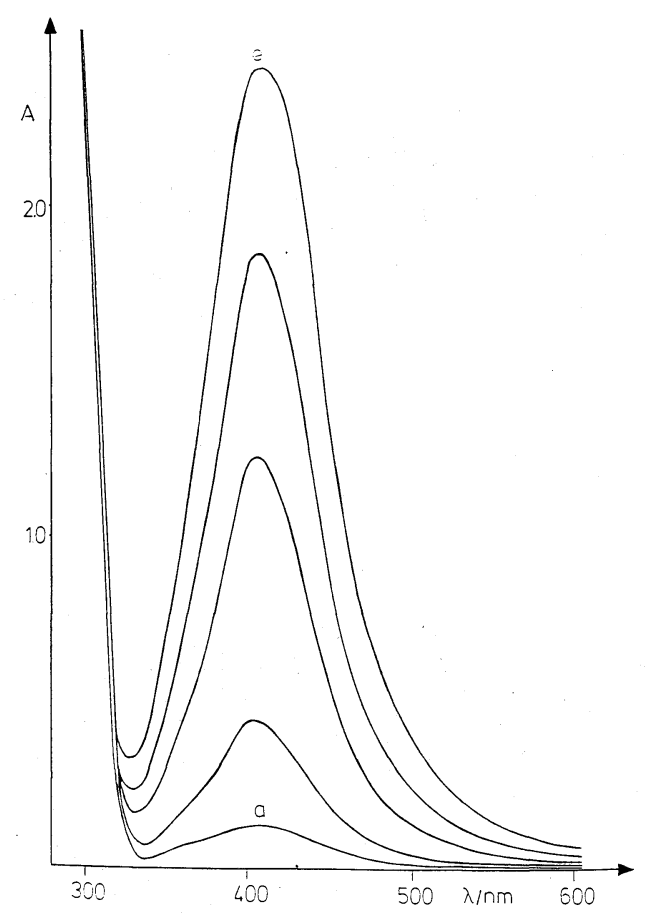

Fig. 5

Spectral changes during the photolysis of $1 \cdot 10^{-3} \mathrm{M}\left[\mathrm{Au}\left(\mathrm{PPh}_{3}\right)_{2} \mathrm{~N}_{3}\right]$ in DMF at (a) 2 and (e) 10 min irradiation time, white light, $1-\mathrm{cm}$ cell

\section{Silver}

The complex $\left[\mathrm{Ag}\left(\mathrm{PPh}_{3}\right)_{2} \mathrm{~N}_{3}\right]$ was light-sensitive in a variety of organic solvents. According to the absorption spectrum of this compound (Fig. 4) the photolysis required light of wavelength below $330 \mathrm{~nm}$. The irradiation led to the evolution of nitrogen, the release of $\mathrm{PPh}_{3}$, and the deposition of metallic silver. Free $\mathrm{PPh}_{3}$ was detected by its fluorescence at $\lambda_{\max }=450 \mathrm{~nm}$. For quantitative analysis the photolyzed solution was evaporated and the residue extracted with hexane. Only $\mathrm{PPh}_{3}$ but not the complex are soluble in hexane. The concentration of $\mathrm{PPh}_{3}$ was determined spectrophotometrically at its absorption maximum $\left(\lambda_{\max }=260 \mathrm{~nm} ; \varepsilon=10000\right)$. In acetonitrile as solvent the quantum yield for the release of $\mathrm{PPh}_{3}$ was $\phi=0.06\left(\lambda_{\text {irr }}=253 \mathrm{~nm}\right)$. The photolysis was also associated with changes of the absorption spectrum of $\left[\mathrm{Ag}\left(\mathrm{PPh}_{3}\right)_{2} \mathrm{~N}_{3}\right]$. However, these spectral changes were small since the absorption spectra of the complex and free $\mathrm{PPh}_{3}$ are very similar. The decrease of absorption around $250 \mathrm{~nm}$ which was observed during the photolysis is partially due to a secondary photolysis of free $\mathrm{PPh}_{3}$.

The photolysis of $\left[\mathrm{Ag}\left(\mathrm{PPh}_{3}\right)_{2} \mathrm{~N}_{3}\right]$ led to the deposition of metallic silver in various forms. Depending on parameters such as the solvent, complex concentration, and light intensity the silver formed a mirror at the cell wall, larger particles which were suspended or precipitated out, or a colloid. The formation of colloidal silver was monitored by its plasmon absorption above $400 \mathrm{~nm}$ (Fig. 5) [37-41]. In later stages of the photolysis or upon standing of the photolyzed solution new absorption bands appeared at longer wavelength. This red shift of the plasmon absorption was associated with color changes of the solution from yellow to reddish and greenish. In chlorinated solvents such as $\mathrm{CH}_{2} \mathrm{Cl}_{2}$ and $\mathrm{CHCl}_{3}$ the plasmon bands were very broad with maxima at rather long wavelength $(\sim 700 \mathrm{~nm})$ even in early stages of the photolysis.

\section{Platinum}

Solutions of $\left[\mathrm{Pt}\left(\mathrm{N}_{3}\right)_{6}\right]^{2-}$ in acetonitrile were not light-sensitive upon long-wavelength irradiation $\left(\lambda_{\text {irr }}>400 \mathrm{~nm}\right)$. When the irradiation was carried out with light of wavelength shorter than $400 \mathrm{~nm}$ an efficient photolysis took place. The evolution of nitrogen was observed. The spectral changes during the photoreaction (Fig. 6) indicated a clean conversion to $\left[\mathrm{Pt}\left(\mathrm{N}_{3}\right)_{4}\right]^{2-}$. At the isosbestic points at 259,224 , and $213 \mathrm{~nm}$ the starting complex $\left[\mathrm{Pt}\left(\mathrm{N}_{3}\right)_{6}\right]^{2-}$ and the product $\left[\mathrm{Pt}\left(\mathrm{N}_{3}\right)_{4}\right]^{2-}$ have the same extinction coefficients. The consumption of $\left[\mathrm{Pt}\left(\mathrm{N}_{3}\right)_{6}\right]^{2-}$ was monitored at $305 \mathrm{~nm}$. At this wavelength the extinction of $\left[\mathrm{Pt}\left(\mathrm{N}_{3}\right)_{4}\right]^{2-}$ was neglected since it was much smaller than that of $\left[\mathrm{Pt}\left(\mathrm{N}_{3}\right)_{6}\right]^{2-}$. At $\lambda_{\text {irr }}=313 \mathrm{~nm}\left[\operatorname{Pt}\left(\mathrm{N}_{3}\right)_{6}\right]^{2-}$ disappeared with a quantum yield of $\phi=0.053$.

Solutions of $\left[\mathrm{Pt}\left(\mathrm{N}_{3}\right)_{4}\right]^{2-}$ are light-sensitive, too. The photolysis of $\left[\operatorname{Pt}\left(\mathrm{N}_{3}\right)_{4}\right]^{2-}$ in acetonitrile $\left(\lambda_{\text {irr }}<300 \mathrm{~nm}\right)$ led to the evolution of nitrogen and the release of azide which was detected as $\mathrm{Fe}(\mathrm{III})$ complex $\left(\lambda_{\max }=460 \mathrm{~nm}, \varepsilon=3680\right)$ [42]. The photoreaction was

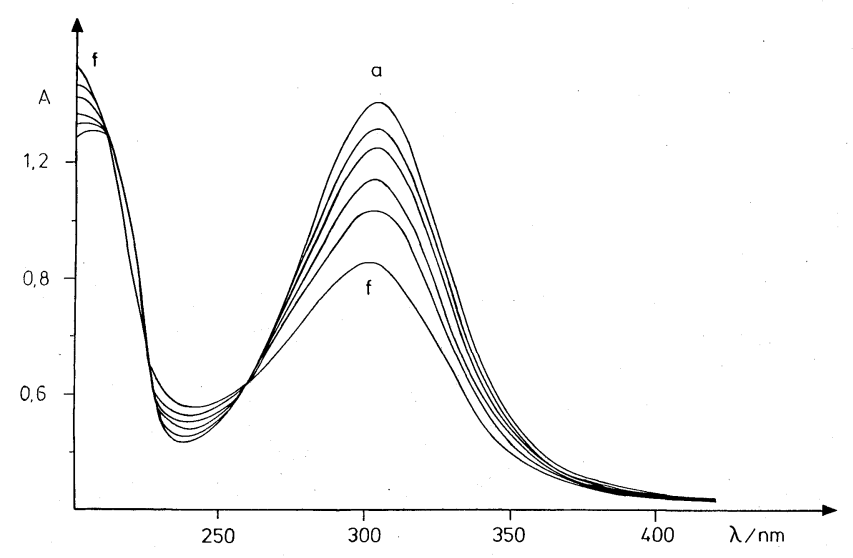

Fig. 6

Spectral changes during the photolysis of $3.85 \cdot 10^{-5} \mathrm{M}\left[\mathrm{Bu}_{4} \mathrm{~N}\right]_{2^{-}}$ $\left[\mathrm{Pt}\left(\mathrm{N}_{3}\right)_{6}\right]$ in $\mathrm{CH}_{3} \mathrm{CN}$ at (a) 0 and (f) 10 min irradiation time, $\lambda_{\text {irr }}=$ $313 \mathrm{~nm}, 1-\mathrm{cm}$ cell 
accompanied by spectral changes as shown in Fig. 7. When the photolysis was complete the product showed a continuous absorption which started in the visible region and increased steadily towards shorter wavelength. At higher concentrations of the complex $\left(c>10^{-3} \mathrm{M}\right)$ this absorption led to the typical brownish color of the photolyzed solution. The disappearance of $\left[\mathrm{Pt}\left(\mathrm{N}_{3}\right)_{4}\right]^{2-}$ was followed by measuring the drop of extinction at its absorption maximum $\left(\lambda_{\max }=255 \mathrm{~nm}, \varepsilon=22500\right)$ taking into account the residual absorption of the photolysis product at this wavelength $(\varepsilon=8600)$. At $\lambda_{\text {irr }}=254 \mathrm{~nm}\left[\mathrm{Pt}\left(\mathrm{N}_{3}\right)_{4}\right]^{2-}$ disappeared with $\theta=0.41$.

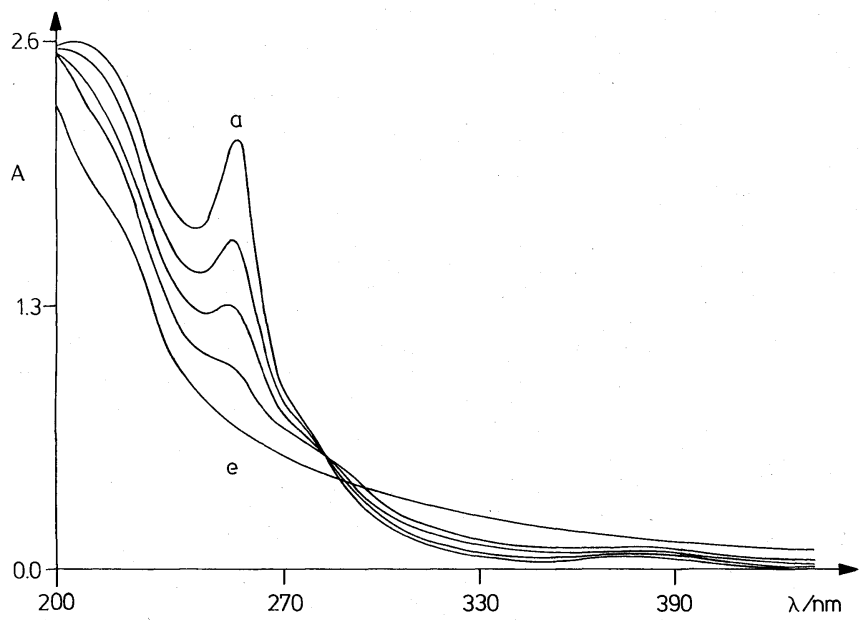

Fig. 7

Spectral changes during the photolysis of $9.42 \cdot 10^{-5} \mathrm{M}\left[\mathrm{Bu}_{4} \mathrm{~N}\right]_{2}$ $\left[\mathrm{Pt}\left(\mathrm{N}_{3}\right)_{4}\right]$ in $\mathrm{CH}_{3} \mathrm{CN}$ saturated with argon at (a) 0 and (e) $60 \mathrm{~min}$ irradiation time, $\lambda_{\text {irr }}=253 \mathrm{~nm}, 1-\mathrm{cm}$ cell

When $5 \cdot 10^{-3} \mathrm{M}\left[\mathrm{Pt}\left(\mathrm{N}_{3}\right)_{4}\right]^{2-}$ in acetonitrile was photolyzed $\left(\lambda_{\text {irr }}>280 \mathrm{~nm}\right)$ in the presence of $5 \mathrm{M}$ allylchloride the complex $\left[\mathrm{C}_{3} \mathrm{H}_{5} \mathrm{PtCl}\right]_{4}$ [43] was formed as photoproduct. This compound which precipitated during the photolysis was identified by comparison of its UV and IR spectrum with those of an authentic sample (IR: $v_{\mathrm{C}-\mathrm{C}}=1488 \mathrm{~cm}^{-1}$ [44]; UV: $\lambda_{\max }=350 \mathrm{~nm} ; \varepsilon=700$ and $\lambda_{\max }=297 \mathrm{~nm}, \varepsilon=1050$ ).

\section{Palladium}

Solutions of $\left[\operatorname{Pd}\left(\mathrm{N}_{3}\right)_{4}\right]^{2-}\left(\lambda_{\max }=324 \mathrm{~nm} ; \varepsilon=17700\right)$ in acetonitrile were thermally not stable. The complex was converted to $\left[\mathrm{Pd}_{2}\left(\mathrm{~N}_{3}\right)_{6}\right]^{2-}\left(\lambda_{\max }=329 \mathrm{~nm} ; \varepsilon=22500\right)$. This conversion was accompanied by spectral changes which showed clear isosbestic points at $238,263,287,366$, and $426 \mathrm{~nm}$. During later stages of this thermal reaction the binuclear complex underwent further reactions as indicated by the loss of these isosbestic points. In the presence of an excess of free azide the conversion of $\left[\mathrm{Pd}\left(\mathrm{N}_{3}\right)_{4}\right]^{2-}$ to $\left[\mathrm{Pd}_{2}\left(\mathrm{~N}_{3}\right)_{6}\right]^{2-}$ was supressed.

The irradiation of $\left[\mathrm{Pd}_{2}\left(\mathrm{~N}_{3}\right)_{6}\right]^{2-}\left(\lambda_{\text {irr }}=313 \mathrm{~nm}\right)$ in acetonitrile led to an efficient photolysis which was accompanied by the evolution of nitrogen. The spectral changes which were observed during the photolysis of solutions saturated with argon are shown in Fig. 8 The final spectrum consists of a continuous absorption which increased towards the UV. The disappearance of $\left[\mathrm{Pd}_{2}\left(\mathrm{~N}_{3}\right)_{6}\right]^{2-}$ was followed by measuring the decrease of the extinction at its absorption maximum $\left(\lambda_{\max }=329 \mathrm{~nm}\right)$ taking into account the residual absorption of the photolysis product at this wavelength $(\varepsilon=6500)$. At $\lambda_{\text {irr }}=313 \mathrm{~nm}\left[\mathrm{Pd}_{2}\left(\mathrm{~N}_{3}\right)_{6}\right]^{2-}$ disappeared with $\phi=6.5 \cdot 10^{-3}$ When the solution was not deaerated the spectral changes indicated the photochemical formation of another product which does not absorb in the visible region. This photoproduct shows a maximum $\lambda_{\max }=273 \mathrm{~nm}$ which disappeared upon prolonged irradiation.

The photolysis of $\left[\operatorname{Pd}\left(\mathrm{N}_{3}\right)_{4}\right]^{2-}\left(\lambda_{\text {irr }}=313 \mathrm{~nm}\right)$ led in the beginning to the formation of $\left[\mathrm{Pd}_{2}\left(\mathrm{~N}_{3}\right)_{6}\right]^{2-}$. The accompanying spectral changes were the same as those observed during the thermal reaction. This photoconversion was monitored by measuring the extinction at $324 \mathrm{~nm}\left(\varepsilon=17700\right.$ for $\left[\operatorname{Pd}\left(\mathrm{N}_{3}\right)_{4}\right]^{2-}$ and 11050 for $\left.\left[\mathrm{Pd}_{2}\left(\mathrm{~N}_{3}\right)_{6}\right]^{2-}\right)$. The quantum yield for this reaction was $\theta=0.019$. However, in distinction to the thermal reaction the photolysis of $\left[\operatorname{Pd}\left(\mathrm{N}_{3}\right)_{4}\right]^{2-}$ led to a loss of the isosbestic points at 237, 260, 298, 370 , and $420 \mathrm{~nm}$ already in early stages. Finally, the product showed the same spectrum as that of the photoproduct of the binuclear complex.

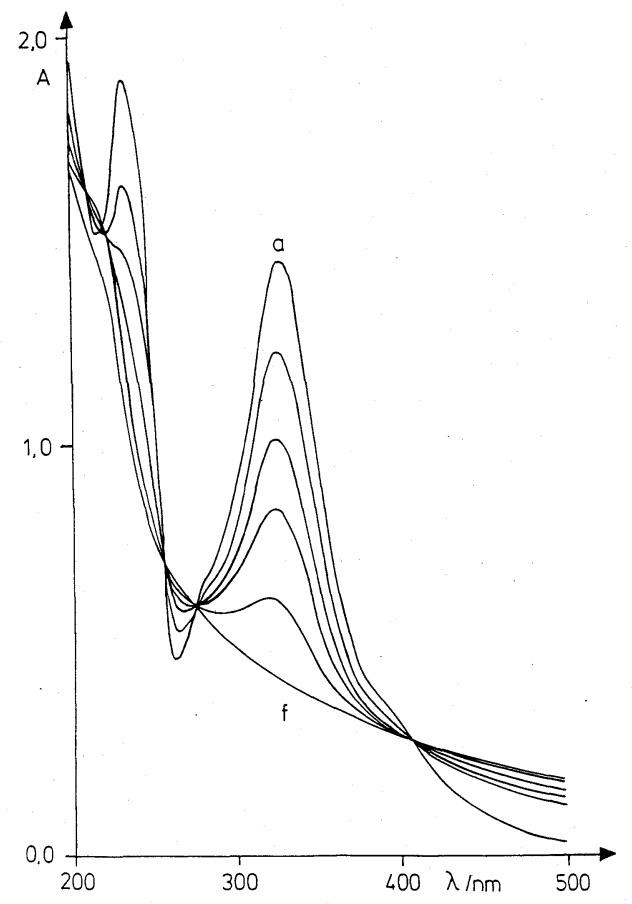

Fig. 8

Spectral changes during the photolysis of $6.44 \cdot 10^{-5} \mathrm{M}\left[\mathrm{Bu}_{4} \mathrm{~N}\right]_{2^{-}}$ $\left[\mathrm{Pd}_{2}\left(\mathrm{~N}_{3}\right)_{6}\right]$ in $\mathrm{CH}_{3} \mathrm{CN}$ saturated with argon at (a) 0 and (f) $10 \mathrm{~min}$ irradiation time, $\lambda_{\mathrm{irr}}=313 \mathrm{~nm}, 1-\mathrm{cm}$ cell

If the photolysis $\left(\lambda_{\text {irr }}=313 \mathrm{~nm}\right)$ of $\left[\operatorname{Pd}\left(\mathrm{N}_{3}\right)_{4}\right]^{2-}$ was carried out in the presence of an excess of free azide $\left(\sim 10^{-2} \mathrm{M}\right)$ the formation of $\left[\mathrm{Pd}_{2}\left(\mathrm{~N}_{3}\right)_{6}\right]^{2-}$ was not observed. The spectra of the photoproducts which were obtained in the presence and absence of air were very similar to the final spectra of the photolysis of $\left[\mathrm{Pd}_{2}\left(\mathrm{~N}_{3}\right)_{6}\right]^{2-}$ under the same conditions. However, the photoreaction of $\left[\operatorname{Pd}\left(\mathrm{N}_{3}\right)_{4}\right]^{2-}$ was much slower $\left(\phi=1.2 \cdot 10^{-3}\right)$ in the presence of free azide than that of the binuclear complex $\left(\phi=6.5 \cdot 10^{-3}\right)$.

The irradiation $\left(\lambda_{\text {irr }}>305 \mathrm{~nm}\right)$ of $\left[\mathrm{Pd}\left(\mathrm{N}_{3}\right)_{4}\right]^{2-}$ in deaerated acetonitrile in the presence of allyl chloride led to the formation of $\left[\left(\mathrm{C}_{3} \mathrm{H}_{5}\right) \mathrm{PdCl}\right]_{2}$. After $30 \mathrm{~min}$ of irradiation the solvent and unreacted $\mathrm{C}_{3} \mathrm{H}_{5} \mathrm{Cl}$ were removed by evaporation. The absorption spectrum of the residue dissolved in $\mathrm{CH}_{3} \mathrm{CN}$ showed clearly the presence of $\left[\left(\mathrm{C}_{3} \mathrm{H}_{5}\right) \mathrm{PdCl}\right]_{2}\left(\lambda_{\max }=325 \mathrm{~nm}, \varepsilon=1432 ; 280 \mathrm{~nm}, 1326 ; 245 \mathrm{~nm}\right.$, 3214) [45]. The spectrum was identical with that of an authentic sample of the complex [46].

\section{Gold}

The absorption spectrum of $\left[\mathrm{Au}\left(\mathrm{N}_{3}\right)_{4}\right]^{-}$(Fig. 1) is characterized by intense bands at $\lambda_{\max }=228 \mathrm{~nm}(\varepsilon=14500)$ and $331 \mathrm{~nm}(\varepsilon=23900)$ which are assigned to ligand to metal charge transfer (LMCT) transition [4, 35]. Ligand field (LF) bands of much lower intensity occur at longer wavelength. Upon LMCT excitation the complex undergoes 
an efficient reductive elimination according to the equation [47]:

$$
\left[\mathrm{Au}^{\mathrm{III}}\left(\mathrm{N}_{3}\right)_{4}\right]^{-} \rightarrow\left[\mathrm{Au}^{\mathrm{I}}\left(\mathrm{N}_{3}\right)_{2}\right]^{-}+3 \mathrm{~N}_{2} \text {. }
$$

The oxidative cleavage of two azide ligands from $\left[\mathrm{Au}\left(\mathrm{N}_{3}\right)_{4}\right]^{-}$ does apparently not occur in a concerted process which was observed for the photolysis of $\left[\mathrm{Pt}\left(\mathrm{PPh}_{3}\right)_{2}\left(\mathrm{~N}_{3}\right)_{2}\right]$ [23]. Beck and Schorpp found evidence that the irradiation of $\left[\mathrm{Au}\left(\mathrm{N}_{3}\right)_{4}\right]^{-}$proceeds via the intermediate formation of azide radicals [5].

The complex $\left[\mathrm{Au}\left(\mathrm{N}_{3}\right)_{2}\right]^{-}$absorbs only below $320 \mathrm{~nm}$. LF bands cannot appear since $\mathrm{Au}(\mathrm{I})$ has a filled d shell. The intense absorption at $\lambda_{\max }=218 \mathrm{~nm}(\varepsilon=15500)$ is assigned to LMCT transition which terminates in the $6 \mathrm{~s}$ orbital of $\mathrm{Au}$. This assignment is also supported by the photochemistry of $\left[\mathrm{Au}\left(\mathrm{N}_{3}\right)_{2}\right]^{-}$.

LMCT excitation of $\left[\mathrm{Au}\left(\mathrm{N}_{3}\right)_{2}\right]^{-}$leads to an efficient photolysis according to the equation:

$\left[\mathrm{Au}^{\mathrm{I}}\left(\mathrm{N}_{3}\right)_{2}\right]^{-} \rightarrow \mathrm{Au}^{0}+1.5 \mathrm{~N}_{2}+\mathrm{N}_{3}^{-}$.

Metallic gold is formed as a colloid which is characterized by the plasmon absorption [36-39]. This band which appears above $500 \mathrm{~nm}$ causes the typical colors of colloidal gold. These may be red, violet or blue depending on the position of the plasmon absorption. According to the Mie theory this position is determined by the size and shape of the colloidal particles, the number of particles per volume unit and the dielectric properties of the surrounding medium $[36-39]$. The band halfwidth is then also a function of the size distribution. By changing the experimental conditions (e. g. solvent, complex concentration, light intensity) the plasmon absorption can be shifted over a large wavelength region. Simple correlations are not apparent. As a typical case the evolution of the plasmon absorption during the photolysis of $\left[\mathrm{Au}\left(\mathrm{N}_{3}\right)_{4}\right]^{-}$in DMF (Fig.3) is discussed shortly.

The first gold particles which are relatively small give rise to a plasmon absorption at $\lambda_{\max }=525 \mathrm{~nm}$. When the photolysis is continued the plasmon absorption becomes more intense and is shifted to longer wavelength until a limit of about $570 \mathrm{~nm}$ is reached. This red shift is an indication of particle growth. In the later stages of the photolysis the appearance of a new band at $\lambda_{\max } \sim 650 \mathrm{~nm}$ can be recognized. It follows that new particles of much larger size are now formed. The formation of these colloidal particles occurs most likely by aggregation of the smaller particles.

The photochemical generation of colloidal gold was reported before [34]. However, it is a unique advantage of the procedure presented in this paper that colloidal gold can be produced under well-controlled conditions in almost every solvent including those which are of very low polarity such as ether, toluene, and $\mathrm{CCl}_{4}$. This observation is certainly of importance with regard to the catalytic properties of colloidal gold $[48,49]$.

It was not the aim of the present study to detect and investigate intermediate stages of the metal aggregation beginning from the generation of metal atoms. Nevertheless, a few relevant observations should be mentioned here since this subject is of great importance. It is assumed that metal atom formation is followed by aggregation to smaller clusters, larger clusters and so on. At some point there may be a transition from molecular species to very small particles which exhibit metallic properties [50]. The plasmon absorption is considered to be a criterion for the metallic state. With regard to this problem the appearance of narrow absorption bands below $240 \mathrm{~nm}$ during the photolysis of $\left[\mathrm{Au}\left(\mathrm{N}_{3}\right)_{2}\right]^{-}$in $\mathrm{CH}_{3} \mathrm{CN}$ is certainly of interest (see results). It is feasible that these bands belong to intermediates which are of sufficient stability in dilute solutions under ambient conditions. For example, gold cluster of various sizes would be good candidates. It can be recognized that the general pattern of the spectral features observed below $240 \mathrm{~nm}$ resembles that of small gold clusters in noble-gas matrices at low temperature [51]. Particularly, the appearance of the two maxima at 204 and $211 \mathrm{~nm}$ is similar to that of the intense short-wavelength bands of $\mathrm{Au}_{2}$ molecules in an argon matrix $\left(\lambda_{\max }=198\right.$ and $\left.208 \mathrm{~nm}\right)$. Diatomic gold should have a considerable stability due to its high bond-strength $\left(221 \mathrm{~kJ} \mathrm{~mol}^{-1}\right)$ [52] in analogy to the isoelectronic $\mathrm{Hg}_{2}^{2+}$ cation. However, upon evaporation of the solvent and redissolution of the residue of the photolysis product the original spectrum (Fig. 2) does not change. It does not seem likely that diatomic gold would survive under these conditions. The short-wavelength bands could therefore belong to the colloidal gold particles. This may have been overlooked in the past since this spectral region is usually obscured by the medium, impurities or other substrates.

\section{Silver}

Homoleptic azide complexes of silver do aparently not exist. The complex $\left[\mathrm{Ag}\left(\mathrm{PPh}_{3}\right)_{2} \mathrm{~N}_{3}\right]$ [9] was chosen as a suitable alternative to study the photochemical behavior of the Ag- $\mathrm{N}_{3}$ moiety. The spectrum of $\left[\mathrm{Ag}\left(\mathrm{PPh}_{3}\right)_{2} \mathrm{~N}_{3}\right]$ (Fig. 4) consists essentially only of the intraligand (IL) absorptions of $\mathrm{PPh}_{3}\left(\lambda_{\max }=250 \mathrm{~nm}, \varepsilon=20000\right)$ which are slightly shifted to higher energies when compared with the free ligand $\left(\lambda_{\max }=260 \mathrm{~nm}, \varepsilon=10000\right)$. However, the free ligand shows a pronounced minimum at $241 \mathrm{~nm}, \varepsilon=$ which appears only as a shallow minimum at $240 \mathrm{~nm}$ in the complex. It is assumed that another band contributes to the intensity of the IL absorption. The most probable origin of such a band is a LMCT transition from the azide to the $5 \mathrm{~s}$ orbital of the oxidizing $\operatorname{Ag}(\mathrm{I})$. This assignment is also supported by the photochemical behavior of the complex.

Light absorption by $\left[\mathrm{Ag}\left(\mathrm{PPh}_{3}\right)_{2} \mathrm{~N}_{3}\right]$ is thus assumed to lead to the LMCT excited state either directly or via the transitory population of the IL excited state of the coordinated $\mathrm{PPh}_{3}$. The LMCT state initiates the photoredox reaction according to the equation:

$$
\left[\mathrm{Ag}\left(\mathrm{PPh}_{3}\right)_{2} \mathrm{~N}_{3}\right] \rightarrow \mathrm{Ag}^{0}+2 \mathrm{PPh}_{3}+1.5 \mathrm{~N}_{2} .
$$

Under suitable conditions the metallic silver forms a colloid which is characterized by its plasmon absorption [37-41]. As discussed for colloidal gold the precise position of this band depends on various parameters. However, the evolution of the plasmon absorption at $\lambda_{\max }=410 \mathrm{~nm}$ (Fig. 5) indicates a rather uniform size distribution with an average particle diameter of about $200 \AA$. In addition, new bands 
appear at longer wavelength. This is certainly due to the agglomeration to larger particles at later stages of the photolysis. In chlorinated solvents (e. g. $\mathrm{CHCl}_{3}$ ) the photolysis of $\left[\mathrm{Ag}\left(\mathrm{PPh}_{3}\right)_{2} \mathrm{~N}_{3}\right]$ leads immediately to rather large particles and a larger distribution of different sizes. The photolysis of $\left[\mathrm{Ag}\left(\mathrm{PPh}_{3}\right)_{2} \mathrm{~N}_{3}\right]$ in $\mathrm{CHCl}_{3}$ was observed before [9]. In this study the photochemical formation of $\left[\mathrm{Ag}\left(\mathrm{PPh}_{3}\right) \mathrm{Cl}\right]_{4}$ was reported to occur. It seems rather reasonable that the silver atoms which are formed in the primary step do not only agglomerate but are reactive enough to abstract chlorine atoms from solvents such as $\mathrm{CHCl}_{3}$ in a competing reaction. In less reactive solvents the agglomeration certainly prevails or taken place exclusively.

The photoreduction of $\mathrm{Ag}^{+}$in aqueous and alcoholic solutions has been described previously $[32,34]$. Nevertheless, our results on the photolytic generation of colloidal silver in non-aqueous solutions could be of particular value with regard to catalytic applications [53].

\section{Platinum}

The electronic spectrum of $\left[\mathrm{Pt}\left(\mathrm{N}_{3}\right)_{6}\right]^{2-}$ displays LF absorptions above $400 \mathrm{~nm}$. Solutions of the complex are not light-sensitive upon LF excitation. At shorter wavelength an intense LMCT band ( $\left.\lambda_{\max }=305 \mathrm{~nm}, \varepsilon=36300\right)$ occurs (Fig. 6). Upon LMCT excitation $\left[\mathrm{Pt}\left(\mathrm{N}_{3}\right)_{6}\right]^{2-}$ underwent an efficient and clean photolysis according to the equation [54]:

$$
\left[\mathrm{Pt}^{\mathrm{IV}}\left(\mathrm{N}_{3}\right)_{6}\right]^{2-} \rightarrow\left[\mathrm{Pt}^{\mathrm{II}}\left(\mathrm{N}_{3}\right)_{4}\right]^{2-}+3 \mathrm{~N}_{2}
$$

Similar photochemical reductive eliminations of other $\mathrm{Pt}(\mathrm{IV})$ azide complexes were observed before [20, 21].

The complex $\left[\mathrm{Pt}\left(\mathrm{N}_{3}\right)_{4}\right]^{2-}$ show LF bands above $300 \mathrm{~nm}$. Light absorption by the LF bands does not cause any chemical change. LMCT absorptions appear in the shorter-wavelength region at $\lambda_{\max }=255 \mathrm{~nm}(\varepsilon=22500)$ and $211 \mathrm{~nm}$ $(\varepsilon=24900)$. CT excitation leads again to a reductive elimination [54]:

$\left[\mathrm{Pt}^{\mathrm{II}}\left(\mathrm{N}_{3}\right)_{4}\right]^{2-} \rightarrow \mathrm{Pt}^{0}+3 \mathrm{~N}_{2}+2 \mathrm{~N}_{3}^{-}$

The absorption spectrum of the photolyzed solutions is apparently due to colloidal platinum [55]. Sometimes the platinum is not formed as the characteristic brownish colloid but separates as larger particles which form a black suspension or precipitate out. In contrast to this observation the photolysis of $\left[\mathrm{Pt}\left(\mathrm{PPh}_{3}\right)_{2}\left(\mathrm{~N}_{3}\right)_{2}\right]$ was shown to generate $\left[\mathrm{Pt}\left(\mathrm{PPh}_{3}\right)_{2}\right]$ by a reductive elimination [23]. It follows that $\mathrm{PPh}_{3}$ as a strong $\pi$-acceptor but not azide is able to stabilize zerovalent platinum.

The platinum which is formed by the photochemical reductive elimination of $\left[\operatorname{Pt}\left(\mathrm{N}_{3}\right)_{4}\right]^{2-}$ may not only agglomerate to larger metallic particles but also react with suitable substrates. The platinum atoms which are certainly very reactive can be intercepted with allyl chloride under mild conditions according to the equation:

$4 \mathrm{Pt}^{0}+4 \mathrm{C}_{3} \mathrm{H}_{5} \mathrm{Cl} \rightarrow\left[\mathrm{C}_{3} \mathrm{H}_{5} \mathrm{PtCl}\right]_{4}$.

It is quite interesting that finely dispersed platinum powder reacts apparently only with the more active allyl iodide [56].
A photochemical production of metallic platinum was recently observed also by Cameron and Bocarsly [33]. It was achieved by the irradiation of $\left[\mathrm{PtCl}_{6}\right]^{2-}$ in the presence of alcohols as reductants. The overall process is thus a fourelectron reduction from $\mathrm{Pt}(\mathrm{IV})$ to $\mathrm{Pt}(0)$. This is quite analogous to the complete photolysis of $\left[\mathrm{Pt}^{\mathrm{IV}}\left(\mathrm{N}_{3}\right)_{6}\right]^{2-}$ which can undergo two successive reductive eliminations yielding finally metallic platinum. The photoredox decomposition of $\left[\operatorname{Pt}\left(\mathrm{N}_{3}\right)_{6}\right]^{2-}$ or $\left[\mathrm{Pt}\left(\mathrm{N}_{3}\right)_{4}\right]^{2-}$ should be also a suitable method to generate metallic platinum under well-controlled conditions for catalytic applications in various areas including photoreactions at semiconductor interfaces and photogeneration of hydrogen $[55,57]$.

\section{Palladium}

The absorption spectrum of $\left[\mathrm{Pd}_{2}\left(\mathrm{~N}_{3}\right)_{6}\right]^{2-}$ in $\mathrm{CH}_{3} \mathrm{CN}$ consists of a LF band at $\lambda_{\max }=400 \mathrm{~nm}(\varepsilon=4800)$ and two LMCT bands at $\lambda_{\max }=235 \mathrm{~nm}(\varepsilon=29500)$ and $329 \mathrm{~nm}$ $(\varepsilon=22500)$ [4] (Fig. 8). LMCT excitation leads to an efficient reductive elimination according to the stoichiometry

$\left[\mathrm{Pd}_{2}\left(\mathrm{~N}_{3}\right)_{6}\right]^{2-} \rightarrow 2 \mathrm{Pd}+2 \mathrm{~N}_{2}+2 \mathrm{~N}_{3}^{-}$.

If the photolysis is carried out in acetonitrile saturated with argon colloidal palladium is formed. This colloid with its typical brown color [58] causes a characteristic absorption spectrum which extends from the visible to the UV with an increasing extinction (Fig. 8). In air-saturated solutions the Pd colloid is not formed. $\operatorname{Pd}(0)$ is apparently intercepted by oxygen. The photoproduct which is characterized by an absorption maximum at $273 \mathrm{~nm}$ may be a $\mathrm{PdO}_{2}$ complex or, more likely, another oxidation product which itself undergoes further photodecomposition.

The electronic spectrum of $\left[\operatorname{Pd}\left(\mathrm{N}_{3}\right)_{4}\right]^{2-}$ in acetonitrile displays a $\mathrm{LF}$ band at $\lambda_{\max }=410 \mathrm{~nm}(\varepsilon=1800)$ and two LMCT absorptions at $\lambda_{\max }=242 \mathrm{~nm}(\varepsilon=16400)$ and $324 \mathrm{~nm}(\varepsilon=17700)[4,35]$. The complex is thermally labile in solution and undergoes a substitution which leads to the formation of the binuclear complex according to:

$$
2\left[\operatorname{Pd}\left(\mathrm{N}_{3}\right)_{4}\right]^{2-} \rightarrow\left[\mathrm{Pd}_{2}\left(\mathrm{~N}_{3}\right)_{6}\right]^{2-}+2 \mathrm{~N}_{3}^{-} .
$$

This reaction takes also place as an efficient photoreaction upon LMCT excitation. It is feasible that the CT excited state is deactivated to a lower-energy LF state which initiates this substitution as a typical photoreaction of LF states. LF excitation at longer wavelength $\left(\lambda_{\text {irr }}=\geq 405 \mathrm{~nm}\right)$ leads to the same result.

In the presence of an excess of free azide the mononuclear complex $\left[\mathrm{Pd}\left(\mathrm{N}_{3}\right)_{4}\right]^{2-}$ in $\mathrm{CH}_{3} \mathrm{CN}$ is only slightly light-sensitive. It is still possible that $\left[\mathrm{Pd}\left(\mathrm{N}_{3}\right)_{4}\right]^{2-}$ undergoes an efficient photosubstitution. However, the binuclear complex is known to react rapidly with $\mathrm{N}_{3}^{-}$to regenerate [Pd$\left.\left(\mathrm{N}_{3}\right)_{4}\right]^{2-}$. LMCT excitation of $\left[\operatorname{Pd}\left(\mathrm{N}_{3}\right)_{4}\right]^{2-}$ in the presence of azide leads to the deposition of metallic palladium but in very low quantum yields. The reductive elimination

$\left[\operatorname{Pd}\left(\mathrm{N}_{3}\right)_{4}\right]^{2-} \rightarrow \operatorname{Pd}(0)+3 \mathrm{~N}_{2}+2 \mathrm{~N}_{3}^{-}$

may thus be a side process originating from the LMCT state. As an alternative the formation of palladium could be also 
caused by the reductive elimination of $\left[\mathrm{Pd}_{2}\left(\mathrm{~N}_{3}\right)_{6}\right]^{2-}$ which might be always present in small amounts by the thermal or photochemical substitution reactions of $\left[\operatorname{Pd}\left(\mathrm{N}_{3}\right)_{4}\right]^{2-}$ even in the presence of free azide.

Upon addition of allyl chloride the photolysis of $\left[\operatorname{Pd}\left(\mathrm{N}_{3}\right)_{4}\right]^{2-}$ or $\left[\operatorname{Pd}_{2}\left(\mathrm{~N}_{3}\right)_{6}\right]^{2-}$ did not lead to the deposition of palladium. The metal atoms as primary photoproduct are apparently scavenged by allyl chloride to yield the wellknown allyl complex [46] according to the equation:

$$
2 \mathrm{Pd}(0)+2 \mathrm{C}_{3} \mathrm{H}_{5} \mathrm{Cl} \rightarrow\left[\left(\mathrm{C}_{3} \mathrm{H}_{5}\right) \mathrm{PdCl}\right]_{2} .
$$

\section{Conclusion}

It has been shown that ligand to metal charge transfer excitation of the azide complexes $\left[\mathrm{Au}\left(\mathrm{N}_{3}\right)_{2}\right]^{-},[\mathrm{Ag}-$ $\left.\left(\mathrm{PPh}_{3}\right)_{2} \mathrm{~N}_{3}\right],\left[\mathrm{Pt}\left(\mathrm{N}_{3}\right)_{4}\right]^{2-},\left[\mathrm{Pd}\left(\mathrm{N}_{3}\right)_{4}\right]^{2-}$, and $\left.\left[\mathrm{Pd}_{2}\left(\mathrm{~N}_{3}\right)_{6}\right)\right]^{2-}$ leads to the oxidation of the azide ligands and the reduction of the metal ions to the metallic state in non-aqueous solvents. Metal colloids which are of great interest for catalytic applications can be generated under well-controlled conditions by this procedure. It is also anticipated that these results provide a good basis for the study of the metal agglomeration process under ambient conditions.

Support of this research by the Deutsche Forschungsgemeinschaft and the Fonds der Chemischen Industrie is gratefully acknowledged.

\section{References}

[1] M. Lindard and H. Flygare, Z. Anorg. Allg. Chem. 262, 328 (1950).

[2] A. W. Adamson, Discuss. Faraday Soc., 29, 163 (1960).

[3] S. A. Penkett and A. W. Adamson, J. Am. Chem. Soc. 87, 2514 (1965).

[4] W. Beck, W. P. Fehlhammer, P. Pöllmann, E. Schuierer, and K. Feldl, Chem. Ber. 100, 2335 (1967).

[5] W. Beck and K. Schorpp, Angew. Chem. Int. Ed. Engl. 9, 735 (1970).

[6] C. Bartocci and F. Scandola, J. Chem. Soc., Chem. Commun. 531 (1970).

[7] J. F. Endicott, M. Z. Hoffman, and L. S. Beres, J. Phys. Chem. 74, 1021 (1970).

[8] A. Vogler, J. Am. Chem. Soc. 93, 5912 (1971).

[9] R. F. Ziolo, J. A. Thich, and Z. Dori, Inorg. Chem. 11, 626 (1972).

[10] a) J. L. Reed, F. Wang, and F. Basolo, J. Am. Chem. Soc. 94, 7173 (1972); b) H. D. Gafney, J. L. Reed, and F. Basolo, J. Am. Chem. Soc. 95, 7998 (1973).

[11] G. Ferraudi and J. F. Endicott, a) J. Am. Chem. Soc. 95, 2371 (1973); b) Inorg. Chem. 12, 2389 (1973).

[12] J. L. Reed, H. D. Gafney, and F. Basolo, J. Am. Chem. Soc. 96, 1363 (1974)

[13] J. I. Zink, Inorg. Chem. 14, 446 (1975).

[14] G. M. Brown, R. W. Callahan, and T. J. Meyer, Inorg. Chem. 14, 1915 (1975).

[15] J. F. Endicott and G. J. Ferraudi, J. Phys. Chem. 80, 949 (1976),

[16] V. M. Miskowski, G. L. Nobinger, and G. S. Hammond, Inorg. Chem. 15, 2904 (1976).

[17] R. Sriram and J. F. Endicott, Inorg. Chem. 16, 2766 (1977).

[18] J. L. Reed, Inorg. Chem. a) 17, 1725 (1978); b) 20, 2590 (1981); c) 21,2829 (1982).

[19] M. Katz and H. D. Gafney, Inorg. Chem. 17, 93 (1978).
[20] A. Vogler, A. Kern, and J. Hüttermann, Angew. Chem. Int. Ed. Engl. 17, 524 (1978).

[21] A. Vogler, A. Kern, and B. Rußeder, Z. Naturforsch. 33 b, 1352 (1978).

[22] R. M. Dahlgren and J. I. Zink, Inorg. Chem. 18, 597 (1979).

[23] A. Vogler, R. E. Wright, and H. Kunkely, Angew. Chem. Int. Ed. Engl. 19, 717 (1980).

[24] A. Vogler and J. Hlavatsch, Angew. Chem. Int. Ed. Engl. 22, 154 (1983).

[25] R. Ngai, Y. L. Wang, and J. L. Reed, Inorg. Chem. 24, 3802 (1985).

[26] G. A. Ozin and S. A. Mitchell, Angew. Chem. Int. Ed. Engl. 22, 674 (1983).

[27] G. Schmidt, Structure and Bonding 62, 51 (1985).

[28] J. R. Blackborow and D. Young, "Metal Vapor Synthesis in Organometallic Chemistry", Springer, Berlin 1979.

[29] K. J. Klabunde, "Chemistry of Free Atoms and Particles, Academic, New York 1980.

[30] G. A. Ozin, M. P. Andrews, L. F. Nazar, H. X. Huber, and C. G. Francis, Coord. Chem. Rev. 48, 203 (1983).

[31] B. C. Gates, L. Guczi, and H. Knözinger (Eds.), "Metal Clusters in Catalysis" (Studies in Surface Science and Catalysis, Vol. 29) Elsevier, Amsterdam 1986.

[32] H. Hada, Y. Yonezawa, A. Yoshida, and A. Kurakake, J. Phys Chem. 80, 2728 (1976).

[33] R. E. Cameron and A. B. Bocarsly, Inorg. Chem. 25, 2910 (1986).

[34] Y. Yonezawa, T. Sato, M. Ohno, and H. Hada, J. Chem. Soc., Faraday Trans. I. 83, 1559 (1987).

[35] H.-H. Schmidtke and D. Garthoff, J. Am. Chem. Soc. 89, 1317 (1967).

[36] J. Turkevich, G. Garton, and P. C. Stevenson, J. Colloid Sci., Suppl. No. 1, 1954, 26.

[37] G. C. Papavassiliou, Prog. Solid. St. Chem. 12, 185 (1978).

[38] C. F. Bohren and D. R. Huffman, "Absorption and Scattering of Litht by Small Particles", Wiley, New York 1983.

[39] J. A. A. J. Perenboom, P. Wyder, and F. Meier, Phys. Rep. 78, 173 (1981).

[40] E. Wiegel, Z. Phys. 136, 642 (1954).

[41] M. Kerker, J. Colloid Interface Sci. 105, 297 (1985).

[42] E. K. Dukes and R. M. Wallace, Anal. Chem. 33, 242 (1961)

[43] J. Lukas, Inorg. Synth. 15, 75 (1974).

[44] B. E. Mann, B. L. Shaw, and G. Shaw, J. Chem. Soc. (A) 3536 (1971).

[45] F. R. Hartley, J. Organometal. Chem. 21, 227 (1970).

[46] Y. Tatsuno, T. Yoshida, and Seiotsuka, Inorg. Synth. 19, 220 (1979).

[47] This reaction was first observed by Beck et al. [4, 5]

[48] D. Meisel, J. Am. Chem. Soc. 101, 6133 (1979).

[49] K. Kopple, D. Meyerstein, and D. Meisel, J. Phys. Chem. 84, 870 (1980).

[50] B. K. Teo, K. Keating, and Y.-H. Kao, J. Am. Chem. Soc. 109, 3494 (1987)

[51] W. E. Klotzbücher and G. A. Ozin, Inorg. Chem. 19, 3767 (1980).

[52] J. Kordis, K. A. Gingerich, and R. J. Seyse, J. Chem. Phys. 61, 5114 (1974).

[53] A. Henglein, a) J. Phys. Chem. 83, 2209 (1079); b) J. Phys. Chem. 83, 2858 (1979); c) Ber. Bunsenges. Phys. Chem. 84, 253 (1980).

[54] Preliminary results were reported previously [24].

[55] P.-A. Brugger, P. Cuendet, and M. Grätzel, J. Am. Chem. Soc. 103, 2923 (1981).

[56] R. D. Rieke, A. V. Kavaliunas, L. D. Rhyne, and D. J. J. Fraser, J. Am. Chem. Soc. 101, 246 (1979).

[57] A. Harriman and M. A. West (Eds.), "Photogeneration of Hydrogen", Academic Press, London 1982.

[58] J. Turkevich and G. Kim, Science 169, 873 (1970).

(Eingegangen am 20. Juni 1988)

E 6853 